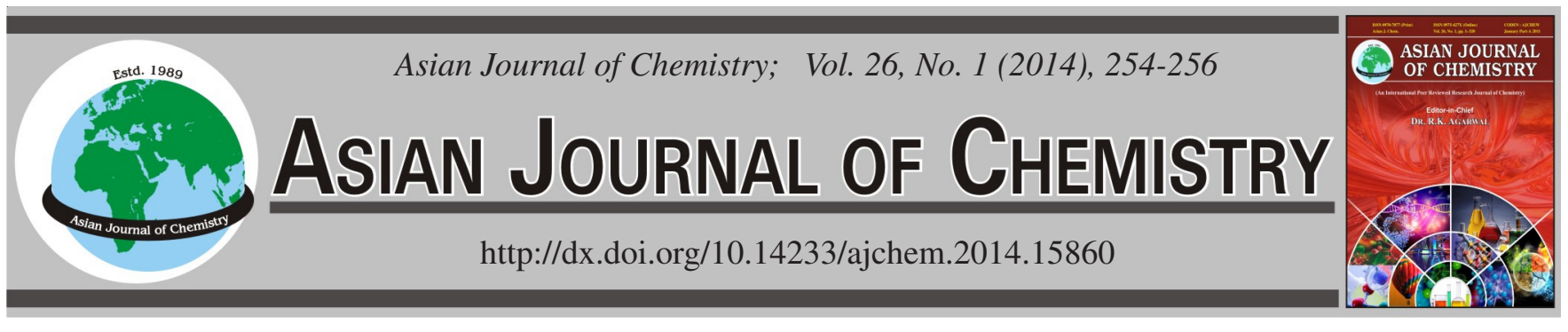

\title{
Chemical Composition, Antifungal Activity and Toxicity of Essential Oils from Leaves of Chimonanthus praecox and Chimonanthus zhejiangensis
}

\author{
Chun-Lian Yu, Yi Kuang, Sheng-Xiang Yang ${ }^{*}$, Li Liu* and ChaO-Gang Liu
}

Zhejiang Provincial Key Laboratory of Chemical Utilization of Forestry Biomass, Zhejiang A \& F University, Lin'an, Zhejiang Province, 311300, China

*Corresponding authors: Tel: +86 571 63732775; E-mail: ysx19821028@yahoo.com.cn; liuli582003@yahoo.com.cn

\begin{abstract}
Essential oils of two Calycanthaceae species, including Chimonanthus praecox and Chimonanthus zhejiangensis, harvested in Hangzhou, Zhejiang province, extracted by hydrodistillation, were analyzed by GC/MS. The antifungal activity of the oils against eight phytopathogenic fungi (Botrytis cinerea, Fusarium graminearum, Fusarium graminearum, Cylindrocarpon destructans, Helminthosporium turcicum, Colletorichum gloeosporioides, Sclerotinia sclerotiorum and Monilinia fructicola) was tested by determining minimum inhibitory concentrations using the microdilution method. The two oils exhibited potent antifungal activities with MIC values of 8-32 $\mu \mathrm{g} / \mathrm{mL}$. The two oils were considered bioactive, showing an $\mathrm{LC}_{50}$ value of 32 and $38 \mu \mathrm{g} / \mathrm{mL}$ in the Artemia salina lethality test.
\end{abstract}

Keywords: Essential oils, Composition, Antifungal activity, Toxicity, Chimonanthus praecox, Chimonanthus zhejiangensis.

\section{INTRODUCTION}

Extracts of aromatic plants, including essential oils, have been used in food, medicine and perfumery for decades, due to their special flavours and functions. Among them, the essential oils are considered to be the most important antimicrobial agents and are suspected to have antioxidant, insecticidal, cytotoxic and antiinflammatory activities as well ${ }^{1}$.

C. praecox and C. zhejiangensis, belong to the Calycanthaceae family, are deciduous Chinese shrub that has survived since the tertiary period. They are both famous traditional fragrant flower plant with high ornamental value in China. Chimonanthus plants are also traditional Chinese herbal medicine for the treatment of colds, analgesic, coughs, asthma and other disorders ${ }^{2}$. In recent years, more attention has been paid to research and development of the essential oil products of Chimonanthus plants. A number of literatures have reported the composition of essential oil extracted from the leaves, flowers and seeds of Chimonanthus plants, such as C. nitens ${ }^{3}$, C. zhejiangensis ${ }^{4}$ and C. praecox ${ }^{5}$.

In the present work, essential oils were extracted from the fresh leaves of $C$. praecox and $C$. zhejiangensi, followed by composition analysis using GC-MS. The antifungal and toxic activities of the extracted oils were especially evaluated. It is noteworthy that the biological activities of the extract of the fresh leaves of $C$. praecox and $C$. zhejiangensi are reported for the first time.

\section{EXPERIMENTAL}

The fresh leaves of $C$. praecox and $C$. zhejiangensis were collected on Hangzhou of Zhejiang province, China. Botanical identification was carried out by Prof. Li Gengyou. Voucher specimens (No. 0270010 and 0270013) of the samples have been deposited with Plant laboratory of Zhejiang A \& F University.

Isolation of essential oil: Dried leaves of C. praecox and C. zhejiangensis were subjected to hydrodistillation for $5 \mathrm{~h}$ and $4 \mathrm{~h}$, resp., using a clevenger-type apparatus. The obtained oils were dried (anh. $\left.\mathrm{Na}_{2} \mathrm{SO}_{4}\right)$ and stored in sealed flasks at $4{ }^{\circ} \mathrm{C}$.

Gas chromatography/mass spectrometry (GC/MS) analysis: GC/MS analysis was carried out using splitless injection mode on a Varian CP3800/1200L GC-MS instrument with a fused silica capillary DB-5MS column (5\% phenylmethylpolysiloxane, $30 \mathrm{~m} \times 0.25 \mathrm{~mm}$, film thickness $0.25 \mu \mathrm{m}$ ). Helium was used as the carrier gas, at a flow rate of $0.8 \mathrm{~mL} / \mathrm{min}$. Oven temperature was programmed at $45^{\circ} \mathrm{C}$ for $3 \mathrm{~min}$, then $45-90{ }^{\circ} \mathrm{C}$ at $10{ }^{\circ} \mathrm{C} / \mathrm{min}$, then $90-180{ }^{\circ} \mathrm{C}$ at $6^{\circ} \mathrm{C} / \mathrm{min}$, then 180 $230{ }^{\circ} \mathrm{C}$ at $12{ }^{\circ} \mathrm{C} / \mathrm{min}$, then $230-250{ }^{\circ} \mathrm{C}$ at $9{ }^{\circ} \mathrm{C} / \mathrm{min}$ and finally held at $250{ }^{\circ} \mathrm{C}$ for $9 \mathrm{~min}$. The injector and detector temperature were set at $250{ }^{\circ} \mathrm{C}$ and $280{ }^{\circ} \mathrm{C}$, respectively. The electron impact source was $70 \mathrm{eV}$, ion source temperature was $200^{\circ} \mathrm{C}$, the mass range 33-450 amu and the scan rate was $0.5 \mathrm{~s}$.

The components of the essential oils were identified by comparison of their $\mathrm{KI}$ (retention indices) relative to $\mathrm{C}_{5}-\mathrm{C}_{24}$ 
$n$-alkanes obtained on a nonpolar DB-5MS column, with those provided in the literature, by comparing their mass spectral fragmentation patterns with those of similar compounds from databases (NIST and Wiley Mass Spectral Libraries) and reported in published articles. For each compound on the gas chromatogram, the percentage of peak area relative to the total peak area of all compounds was determined and reported as relative amount of that compound, without using correction factors.

Antifungal bioassay: The test phytopathogenic fungi used in this study were Botrytis cinerea, Fusarium graminearum, Fusarium graminearum, Cylindrocarpon destructans, Helminthosporium turcicum, Colletorichum gloeosporioides, Sclerotinia sclerotiorum and Monilinia fructicola. All the fungi were isolated from infected plant organs at the Zhejiang A\&F University.

Antifungal activity was assessed by the microbroth dilution method in 96-well culture plates using a potato dextrose medium $^{6}$.The serial doubling dilution of the essential oil and its major compound was prepared in dimethyl sulfoxide, with concentrations ranging from 0.25 to $32 \mu \mathrm{g} / \mathrm{mL}$. Final concentration of DMSO never exceeded $2 \%$. A commercial fungicide carbendazim (Aladdin Chemistry Co. Ltd.) was used as positive control and the solution of equal concentration of DMSO was

TABLE-1

CHEMICAL COMPOSITION OF THE LEAVE ESSENTIAL OILS OF C. praecox AND C. zhejiangensis

\begin{tabular}{|c|c|c|c|c|c|}
\hline \multirow{2}{*}{ Compounds } & \multirow{2}{*}{ m.f. } & \multirow{2}{*}{ RT } & \multirow{2}{*}{ RI } & \multicolumn{2}{|c|}{ Relative content $(\%)$} \\
\hline & & & & C. praecox & C. zhejiangensi \\
\hline 1S- $\alpha$-Pinene & $\mathrm{C}_{10} \mathrm{H}_{16}$ & 4.7105 & 931 & - & 1.25 \\
\hline 1R- $\alpha$-Pinene & $\mathrm{C}_{10} \mathrm{H}_{16}$ & 4.7321 & 932 & 8.01 & - \\
\hline Camphene & $\mathrm{C}_{10} \mathrm{H}_{16}$ & 5.1000 & 946 & 0.10 & 4.70 \\
\hline$\beta$-Phellandrene & $\mathrm{C}_{10} \mathrm{H}_{16}$ & 5.7492 & 971 & 1.43 & \\
\hline$\beta$-Pinene & $\mathrm{C}_{10} \mathrm{H}_{16}$ & 5.8358 & 974 & 3.02 & 0.16 \\
\hline$\beta$-Myrcene & $\mathrm{C}_{10} \mathrm{H}_{16}$ & 6.2686 & 991 & 2.04 & 1.41 \\
\hline$\alpha$-Phellandrene & $\mathrm{C}_{10} \mathrm{H}_{16}$ & 6.658 & 1004 & 2.30 & - \\
\hline Eucalyptol & $\mathrm{C}_{10} \mathrm{H}_{18} \mathrm{O}$ & 7.5237 & 1029 & 39.44 & 2.16 \\
\hline$\beta$-Ocimene & $\mathrm{C}_{10} \mathrm{H}_{16}$ & 8.1512 & 1046 & 0.96 & 0.39 \\
\hline$\gamma$-Terpinene & $\mathrm{C}_{10} \mathrm{H}_{16}$ & 8.4974 & 1056 & 0.25 & - \\
\hline (+)-4-Carene & $\mathrm{C}_{10} \mathrm{H}_{16}$ & 9.5794 & 1087 & 0.15 & 0.07 \\
\hline Linalool & $\mathrm{C}_{10} \mathrm{H}_{18} \mathrm{O}$ & 10.0772 & 1101 & 0.26 & 0.36 \\
\hline Borneol & $\mathrm{C}_{10} \mathrm{H}_{17} \mathrm{OH}$ & 12.7172 & 1165 & - & 5.43 \\
\hline 4-Terpineol & $\mathrm{C}_{10} \mathrm{H}_{18} \mathrm{O}$ & 13.1283 & 1175 & 0.86 & 0.15 \\
\hline Geraniol & $\mathrm{C}_{10} \mathrm{H}_{18} \mathrm{O}$ & 16.5257 & 1255 & 1.36 & 0.91 \\
\hline Bornyl acetate & $\mathrm{C}_{12} \mathrm{H}_{20} \mathrm{O}_{2}$ & 17.9540 & 1289 & - & 23.29 \\
\hline$\gamma$-Limonene & $\mathrm{C}_{10} \mathrm{H}_{16}$ & 19.0792 & 1315 & 1.54 & 0.06 \\
\hline Terpilene & $\mathrm{C}_{10} \mathrm{H}_{16}$ & 20.4641 & 1348 & 4.43 & - \\
\hline Geranyl Acetate & $\mathrm{C}_{12} \mathrm{H}_{20} \mathrm{O}_{2}$ & 22.0006 & 1385 & 0.64 & 4.17 \\
\hline$\beta$-Elemen & $\mathrm{C}_{15} \mathrm{H}_{24}$ & 22.1520 & 1388 & 0.20 & 0.13 \\
\hline Caryophyllene & $\mathrm{C}_{15} \mathrm{H}_{24}$ & 23.2989 & 1418 & 3.92 & 1.70 \\
\hline$\alpha$-Caryophyllene & $\mathrm{C}_{15} \mathrm{H}_{24}$ & 24.7704 & 1460 & 1.28 & 0.70 \\
\hline (+)-Epi-bicyclosesquiphellandrene & $\mathrm{C}_{15} \mathrm{H}_{24}$ & 25.4413 & 1479 & 0.09 & 0.34 \\
\hline Germacrene D & $\mathrm{C}_{15} \mathrm{H}_{24}$ & 25.6360 & 1485 & 2.42 & 1.00 \\
\hline$\gamma$-Elemene & $\mathrm{C}_{15} \mathrm{H}_{24}$ & 26.0039 & 1495 & 1.76 & - \\
\hline$\alpha$-Muurolene & $\mathrm{C}_{15} \mathrm{H}_{24}$ & 26.0905 & 1498 & 1.18 & - \\
\hline Longifolenaldehyde & $\mathrm{C}_{15} \mathrm{H}_{24} \mathrm{O}$ & 26.1338 & 1499 & - & 1.08 \\
\hline$\alpha$-Farnesene & $\mathrm{C}_{15} \mathrm{H}_{24}$ & 26.3501 & 1511 & 0.89 & - \\
\hline$\delta$-Cadinene & $\mathrm{C}_{15} \mathrm{H}_{26}$ & 26.5882 & 1525 & 2.30 & - \\
\hline Aromadendrene oxide-(1) & $\mathrm{C}_{15} \mathrm{H}_{24} \mathrm{O}$ & 26.9561 & 1547 & - & $0 . .47$ \\
\hline Alloaromadendrene oxide-(1) & $\mathrm{C}_{15} \mathrm{H}_{24} \mathrm{O}$ & 27.1292 & 1558 & - & 0.31 \\
\hline (-)-Alloaromadendrene & $\mathrm{C}_{15} \mathrm{H}_{24}$ & 27.1508 & 1559 & 0.34 & - \\
\hline 4-Hexadecen-6-yne, (E)- & $\mathrm{C}_{15} \mathrm{H}_{24} \mathrm{O}$ & 27.3240 & 1570 & & 4.87 \\
\hline (-)-Spathulenol & $\mathrm{C}_{15} \mathrm{H}_{24} \mathrm{O}$ & 27.4754 & 1579 & 0.60 & \\
\hline Furan, 3-(4,8-dimethyl-3,7-nonadienyl)-, (E)- & $\mathrm{C}_{15} \mathrm{H}_{22} \mathrm{O}$ & 27.5404 & 1583 & - & 18.21 \\
\hline$(+)-\gamma$-Gurjunene & $\mathrm{C}_{15} \mathrm{H}_{24}$ & 27.5620 & 1584 & 0.46 & - \\
\hline Carotol & $\mathrm{C}_{15} \mathrm{H}_{26} \mathrm{O}$ & 27.8217 & 1600 & - & 1.55 \\
\hline$\alpha$-Cedrene & $\mathrm{C}_{15} \mathrm{H}_{24}$ & 28.1679 & 1630 & 0.55 & 0.68 \\
\hline$\lambda$-Muurolol & $\mathrm{C}_{15} \mathrm{H}_{26} \mathrm{O}$ & 28.3626 & 1647 & 3.01 & - \\
\hline 6,6,10-Trimethylundeca-3,8,10-triene-2,7-dione & $\mathrm{C}_{14} \mathrm{H}_{20} \mathrm{O}_{2}$ & 28.4276 & 1653 & - & 4.25 \\
\hline$\gamma$-Cadinene & $\mathrm{C}_{15} \mathrm{H}_{26}$ & 28.5141 & 1660 & 4.48 & - \\
\hline Calarene epoxide & $\mathrm{C}_{15} \mathrm{H}_{24} \mathrm{O}$ & 28.6873 & 1675 & - & 2.44 \\
\hline 1,4,7,-Cycloundecatriene,1,5,9,9-tetramethyl-, Z,Z,Z- & $\mathrm{C}_{15} \mathrm{H}_{24}$ & 29.0768 & 1712 & - & 3.05 \\
\hline 2Z,6E-Farnesol & $\mathrm{C}_{15} \mathrm{H}_{26} \mathrm{O}$ & 29.2066 & 1726 & 0.44 & 1.86 \\
\hline Santalol & $\mathrm{C}_{15} \mathrm{H}_{24} \mathrm{O}$ & 29.4230 & 1750 & - & 0.32 \\
\hline (-)-Isolongifolol, methyl ether & $\mathrm{C}_{15} \mathrm{H}_{24} \mathrm{O}$ & 29.5312 & 1762 & - & 1.31 \\
\hline$(+)$ - $\alpha$-Elemene & $\mathrm{C}_{15} \mathrm{H}_{24}$ & 29.7476 & 1786 & 0.30 & - \\
\hline 1,6-Octadien-3-ol, 4,7-dimethyl-, isovalerate & $\mathrm{C}_{10} \mathrm{H}_{18} \mathrm{O}$ & 30.0073 & 1816 & - & 0.95 \\
\hline
\end{tabular}


used as a negative control. The tested fungi were incubated in the potato dextrose medium for $18 \mathrm{~h}$ at $28 \pm 0.5^{\circ} \mathrm{C}$ at $150 \mathrm{rpm}$ and spores of different microorganism concentrations were diluted to approximately $1 \times 10^{6} \mathrm{CFU}$ with potato dextrose medium. The test oils $(10 \mu \mathrm{L})$ were added to 96 -well microplates and $90 \mu \mathrm{L}$ of potato dextrose medium was added. Serial dilutions were made in the 96-well round-bottom sterile plates in triplicate in $50 \mu \mathrm{L}$ of potato dextrose medium and then $50 \mu \mathrm{L}$ of the fungal suspension was added. After incubation for $48 \mathrm{~h}$ at $28 \pm 0.5^{\circ} \mathrm{C}$, minimum inhibitory concentration (MIC) was taken as the lowest concentration of the test compounds in the wells of the 96-well plate in which no microbial growth could be observed.

Brine shrimp lethality bioassay: The essential oils of $C$. praecox and $C$. zhejiangensis were assayed using a modified test of lethality to A. salina ${ }^{7}$. The eggs of $A$. salina were incubated in a hatching chamber with seawater and kept at room temperature (average $27{ }^{\circ} \mathrm{C}$ ) under artificial light around the clock. Larvae after $48 \mathrm{~h}$ were extracted and counted using a Pasteur pipette. A standard solution of $1,000 \mu \mathrm{g} / \mathrm{mL}$ was prepared with $100 \mathrm{mg}$ of essential oil diluted in $1 \mathrm{~mL}$ of DMSO and the volume was completed with seawater in a 100 $\mathrm{mL}$ volumetric flask. Concentrations of 900, 100, 10 and $1 \mu \mathrm{g} / \mathrm{mL}$ were prepared using standard solution. For each concentration, 10 brine shrimp larvae were used, placed in flasks that were filled with seawater to a total volume of $5 \mathrm{~mL}$. Intermediate concentrations were made to calculate the $\mathrm{LC}_{50}$. For the control group, a solution was prepared with $100 \mu \mathrm{L}$ of DMSO and $4.9 \mathrm{~mL}$ of seawater. After $24 \mathrm{~h}$, the dead larvae were counted and the $\mathrm{LC}_{50}$ value was estimated using the Origin 7.0 statistical program.

\section{RESULTS AND DISCUSSION}

The oil yield for $C$. praecox was $1.5 \%$ (v/w), with 35 compounds identified that represented $95.94 \%$ of the oil content. The main components were eucalyptol (39.44\%), 1R- $\alpha$-pinene $(8.01 \%), p$-menth-1-en-8-ol (4.82\%), $\gamma$-cadinene $(4.48 \%)$ and terpilene (4.43\%; Table- 1$)$. A number of studies on essential oil content and constituents from the flowers and seeds of $C$. praecox have been performed. However, these results differ from our findings. Si et al. ${ }^{5}$ showed that supercritical carbon dioxide extraction of the essential oil detected 57 compounds in the flowers from cultivated sources, with benzyl alcohol (28.48 \%), cadinol (14.61\%) and bornyl acetate $(6.52 \%)$ as the major constituents. Thus, essentialoil-bearing plants usually show a variable chemical composition due to both intrinsic (sexual, seasonal, ontogenetic and genetic variations) and extrinsic (ecological and environmental aspects) factors.

The yield of oil from $C$. zhejiangensis was $2.5 \%(\mathrm{v} / \mathrm{w})$, higher that the yield obtained from C. praecox. GC/MS identified 35 compounds, representing $91.42 \%$ of the oil content. Bornyl acetate and 3-(4,8-dimethyl-3, 7-nonadienyl)furan, (E)- were the main monoterpene hydrocarbons accounting for 23.29 and $18.21 \%$, respectively of the chromatograms (Table-1). Interestingly, 1,4-cineole, trioctylamine, caryophyllene and $\alpha$-terpinylpropionate which were described in an earlier report to be the major constituents of $C$. zhejiangensis oil ${ }^{4}$ were either not detected or present at trace levels in our analysis.

Evaluation of MIC values of the oils showed a variability of inhibition among all the fungi tested $(8-32 \mu \mathrm{g} / \mathrm{mL})$ (Table-2). According to these activity ranks, the essential oils of $C$. praecox and $C$. zhejiangensis showed a effective antifungal activity against most of the tested strains, which could be attributed to the high content of the oils, of compounds with known antimicrobial activity, such as linalool, (-)-spathulenol and caryophyllene. Against F. graminearum, C. destructans and $M$. fructicola, the $C$. zhejiangensi oil was more active than the C. praecox oil. The fungistatic properties of the oils are suspected to be associated with the high content of terpenes type components ${ }^{8}$. On the other hand, it is also possible that the minor components might be involved in some type of synergism with the other active compounds. The observed antifungal activity is of importance, because fungal infections have increased considerably, attributed to its intrinsic resistance to commercial fungicides.

\begin{tabular}{lccc}
\multicolumn{4}{c}{ TABLE-2 } \\
ANTIFUNGAL AACTIVITY OF THE ESSENTIAL OILS \\
OF C. praecox AND C. zhejiangensis AGAINST EIGHT \\
PHYTOPATHOGENIC FUNGI STRAINS \\
\hline \multirow{2}{*}{ Phytopathogenic fungi } & \multicolumn{3}{c}{ MIC $(\mu \mathrm{g} / \mathrm{mL}(\mathrm{m} / \mathrm{v}))$} \\
\cline { 2 - 4 } & praecox & zhejiangensi & Carbendazim \\
\hline Fusarium graminearum & 32 & 8 & 8 \\
Fusarium graminearum & 32 & 16 & 8 \\
Botrytis cinerea & 32 & 16 & 8 \\
Cylindrocarpon destructans & 32 & 8 & 4 \\
Monilinia fructicola & $>32$ & 16 & 8 \\
Sclerotinia sclerotiorum & 16 & 32 & 8 \\
Helminthosporium turcicum & 16 & 32 & 4 \\
Colletorichum gloeosporioides & 16 & 32 & 8 \\
\hline
\end{tabular}

In the evaluation of plant extract toxicity by the brine shrimp bioassay, an $\mathrm{LC}_{50}$ value lower than $1,000 \mu \mathrm{g} / \mathrm{mL}$ is considered bioactive ${ }^{7}$. In this study, the essential oils from of C. praecox and $C$. zhejiangensi exerted an $\mathrm{LC}_{50}$ values of 32 and $38 \mu \mathrm{g} / \mathrm{mL}$, respectively, suggesting that the two oils have powerful toxic activities.

\section{ACKNOWLEDGEMENTS}

This work was supported by the National Natural Science Foundation of China (Grant No. 31200262 and 31270619) and Talent Foundation of Zhejiang A \& F University (Grant No. 2012FR041).

\section{REFERENCES}

1. D.J. Daferera, B.N. Ziogas and M.G. Polissiou, J. Agric. Food Chem., 48, 2576 (2000).

2. P.G. Xiao, Modern Chinese Material Medica, Beijing, Chemical Industry Press, vol. 3, p. 388 (2001).

3. R.G. Shu, S.S. Li and P.Z. Zhang, Chin. J. Hospital Pharm., 30, 761 (2010).

4. Y.T. Ou and X. Mai, J. Chin. Med. Mater, 33, 385 (2010).

5. H.Q. Si, Q. Shen X.L. Pang and X.L. Pang Food Sci., 31, 134 (2010).

6. M.J. Gonçalves, A.C. Tavares, C. Cavaleiro, M.T. Cruz, M.C. Lopes, J. Canhoto and L. Salgueiro, Ind. Crop. Prod., 39, 204 (2012).

7. B.N. Meyer, N.R. Ferrigni, J.E. Putnana, L.B. Jacobsen, D.E. Nichols, and J. McLaughlin, Planta Med., 45, 31 (1982).

8. F. Deba, T.D. Xuan, M. Yasuda and S. Tawata Food Control, 19, 346 (2008). 